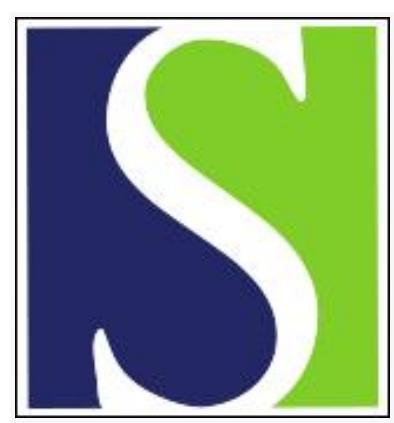

Scand J Work Environ Health 1987;13(3):247-251

https://doi.org/10.5271/sjweh.2056

Issue date: Jun 1987

Mortality in two cohorts of welders exposed to high- and low-levels of hexavalent chromium.

by Sjogren B, Gustavsson A, Hedstrom L

This article in PubMed: www.ncbi.nlm.nih.gov/pubmed/3616554

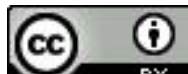




\title{
Mortality in two cohorts of welders exposed to high- and low-levels of hexavalent chromium
}

\author{
by Bengt Sjögren, MD, Annika Gustavsson, Lars Hedström, MSc ${ }^{1}$
}

\begin{abstract}
SJÖGREN B, GUSTAVSSON A, HEDSTRÖM L. Mortality in two cohorts of welders exposed to highand low-levels of hexavalent chromium. Scand J Work Environ Health 13 (1987) 247-251. Hexavalent chromium particles are generated in the welding of stainless steel. These particles have manifested a mutagenic action in bacterial test systems and produced chromosome aberrations in cultured Chinese hamster cells. A cohort consisting of 234 welders working on stainless steel and exposed to high levels of chromium was selected. According to an earlier survey the hexavalent chromium exposure of such welders was often above $20 \mu \mathrm{g} / \mathrm{m}^{3}$. Another cohort consisting of 208 railway track welders exposed to low levels of chromium was also selected. The participants of both cohorts had welded for at least five years some time between 1950 and 1965 and were followed for mortality until December 1984. Among the welders exposed to high chromium levels five deaths occurred due to pulmonary tumors. This number is significantly greater than the one death that occurred among the welders exposed to low levels of chromium, but not significantly greater than the corresponding mortality of the general population. Thus exposure to stainless steel welding fumes might be associated with an increased incidence of pulmonary tumors.
\end{abstract}

Key terms: pulmonary tumors, stainless steel.

Stainless steel is usually welded by one of two electricarc methods, one using coated electrodes and the other a shielding gas. In both these methods an electric voltage creates an arc between the electrode and the welded material. The coated electrodes produce gases and slag which protect the splice against the oxidational power of the air. This method is also called manual metal-arc welding. In gas-shielded welding an inert gas, argon, protects the splice against the air. This method is further subdivided into metal inert-gas (MIG) welding, using a consumable electrode, and tungsten inertgas (TIG) welding, using a nonconsumable electrode.

A survey of welders working with stainless steel in Sweden was performed in 1974 (6). About 400 persons carried out welding with coated electrodes, and about 500 persons carried out gas-shielded welding for more than $50 \%$ of their worktime.

Stainless steel is an alloy which contains mainly iron but also chromium $(10-20 \%)$ and nickel $(0.5-20 \%)$. The electrodes used contain about the same amount of chromium and nickel. The chromium in airborne particles is mainly in the soluble hexavalent form when coated electrodes are used for welding. Gas-shielded welding produces much less hexavalent chromium (5, $14,27,28,29)$.

Bacteria tests have shown fumes from coatedelectrode stainless steel welding to be more mutagenic

\footnotetext{
1 Section of Occupational Medicine, Research Department, National Board of Occupational Safety and Health, Solna, Sweden.
}

Reprint requests to: Dr B Sjögren, Section of Occupational Medicine, Research Department, National Board of Occupational Safety and Health, S-171 84 Solna, Sweden. than fumes from gas-shielded welding. Fumes from mild steel welding have no mutagenic effect $(8,16)$. Fume particles from stainless steel have also been shown to produce sister chromatid exchanges and chromosome aberrations in cultured Chinese hamster cells (12). Stainless steel welding fume has also been positive in other mammalian cell transformation assays (7). Welders working with coated electrodes on stainless steel had equal amounts of sister chromatid exchanges and chromosome aberrations in their peripheral blood lymphocytes when compared with unexposed referents $(11,15)$. However, welders working about equal times at MIG welding and welding with coated electrodes had a slight but significant increase in the number of chromosome aberrations (13).

Some epidemiologic studies of welders in general have shown a 30-40\% increase in the incidence of pulmonary tumors (26). Asbestos $(2,21)$ and hexavalent chromium (22) are two possible causative agents. A well-conducted case-referent study has revealed an increased incidence of nasal and sinonasal tumors among welders exposed to chromium (9).

The purpose of this study was to investigate mortality and the incidence of tumors in two groups of welders. One group was exposed to high levels of hexavalent chromium and the other group to low levels.

\section{Subjects and methods}

\section{High-exposure cohort}

Eight different companies, from Lund in the south to Avesta in the north of Sweden, provided lists of welders. These lists did not specify welding method or the 
material which was welded. A person (often an old welder) with knowledge of all the presently and previously employed welders at the company selected welders who had welded stainless steel as the main task for at least five years some time between 1950 and 1965 . Name, ten-digit identification number based on date of birth, and the most used welding method were registered for all the welders. The selected cohort consisted of 234 men. Most of them had welded with coated electrodes. Gas-shielded welding, most frequently TIG, was performed by only a small number of welders. The eventual mortality of the welders was traced through the registration books of their local parishes until December 1977, and this outcome has been published (22).

\section{Low-exposure cohort}

The welders exposed to low levels of chromium consisted of railway track welders working at the Swedish State Railways for at least five years some time between 1950 and 1965 . All the welders identified in the registers of the company and working during this specific time were selected. The welders were identified by name and ten-digit identification number. The cohort consisted of 208 men from Malmö in the south to Luleå in the north of Sweden.

\section{Calculations}

The two cohorts have been followed until December 1984. The mortality of the welders was traced through the registers of the National Social Insurance Office and the local parishes. All the members of the cohorts could be identified in these registers. All the death certificates were checked against the classification made by the Swedish National Central Bureau of Statistics. The expected numbers of deaths in the two cohorts were calculated by the multiplication of the personyears of observation within five-year age categories during 1955 - 1984 by cause-, gender-, age-class-, and calendar-year-specific national death rates provided by the same bureau of statistics. The rates for 1982-1984 were not yet available and therefore have been approximated according to the rates of 1981. The EPILIN program (1) was utilized to calculate these expectancy numbers. Person-years at risk were calculated after the minimum five-year exposure period.

The high-exposure cohort was also compared with the low-exposure cohort. The Mantel-Haenszel method was used to calculate rate ratios after stratification for age (18). Confidence limits have been derived by the use of the test-based principle (18).

\section{Exposure}

\section{High-exposure cohort}

Air pollution in stainless steel welding was surveyed in Sweden in 1975 (29). The median time-weighted average value for chromium was $110 \mu \mathrm{g} / \mathrm{m}^{3}$, and the highest concentration was $750 \mu \mathrm{g} / \mathrm{m}^{3}$, which was found in welding involving coated electrodes. Eighty-five percent of the 85 chromium measurements exceeded 50 $\mu \mathrm{g} / \mathrm{m}^{3}$, which was the occupational exposure limit (OEL) for chromium trioxide in Sweden in 1975. In gas-shielded welding the median chromium concentration was $10 \mu \mathrm{g} / \mathrm{m}^{3}$, and the highest concentration $440 \mu \mathrm{g} / \mathrm{m}^{3}$. The majority of these measurements was made when workers were performing TIG welding. About one-third of the 41 chromium measurements exceeded the OEL. However, only a minor fraction of the chromium was in the hexavalent form.

Measurements of stainless steel welding fumes do not exist for the period 1950-1965. Representatives from the eight companies from which the cohort was selected had the impression that particle exposure was similar to that of 1975 . In some workshops the welding fume exposure was assumed to have been somewhat higher 25 years ago.

In some workshops, asbestos had been used earlier for heat insulation. Welders were included in the cohort only if representatives from the companies stated that asbestos had not been used or only very occasionally and never in a dust-generating way. Measurements of airborne asbestos had never been performed in any of the companies during the period 1950-1965.

\section{Low-exposure cohort}

The most commonly used welding technique during 1950-1965 was thermite welding for joining rails and gas-welding to produce the overlayer of rails. Chromium is not involved in thermite welding, and the hexavalent chromium fume content in overlaying by gas is probably lower than a few percent of the chromium content when coated electrodes are used (5). In the beginning of the 1970 s coated electrodes were more frequently used for the overlaying of rails. The electrode used for this type of welding contained $3.2 \%$ chromium, and the geometric mean of 33 measurements of chromium performed in 1975 was $10 \mu \mathrm{g} / \mathrm{m}^{3}$ (30).

Asbestos has been used as a plug in thermite welding, but it has not been used in a dust-generating way.

\section{Results}

At the end of 1977 the number of deaths among the high-exposure cohort of welders was slightly lower than expected, based on the national death rates (table 1). The number of deaths occurring in this cohort during the next seven years was lower than expected, the result being a low, but not significantly lower, total number of deaths at the end of 1984 (table 2). The total number of tumors was equal to the number expected. Five welders had died from pulmonary tumors. This number was not significantly greater than the expected 
number. Different histological types of tumors were seen, ie, three squamous cell carcinomas, one adenocarcinoma, and one nondifferentiated pulmonary tumor.

In the low-exposure cohort the total number of deaths was significantly lower than the expected number based on the national rates (table 3 ). The number of deaths due to tumors and ischemic heart disease was lower, but not significantly lower, than expected.

Table 1. Observed $(O)$ and expected $(E)$ number of deaths among 234 welders exposed to high levels of chromium and followed until December 1977 and from 1978 until December 1984. The expected numbers are based on the national rates.

\begin{tabular}{|c|c|c|c|c|}
\hline \multirow{2}{*}{ Cause of deatha } & \multicolumn{2}{|c|}{$\begin{array}{l}\text { Until December } \\
1977\end{array}$} & \multicolumn{2}{|c|}{$\begin{array}{c}1978 \text { until } \\
\text { December } 1984\end{array}$} \\
\hline & 0 & $E$ & $\mathrm{O}$ & $E$ \\
\hline All $(1-999)$ & 18 & 22.2 & 14 & 22.0 \\
\hline All tumors $(140-209)$ & 4 & 5.1 & 6 & 5.4 \\
\hline $\begin{array}{l}\text { Tumor of trachea, } \\
\text { bronchus and lung (162) }\end{array}$ & 3 & 0.9 & 2 & 1.1 \\
\hline $\begin{array}{l}\text { Ischemic heart disease } \\
(410-414)\end{array}$ & 6 & 6.4 & 4 & 8.9 \\
\hline Violent deaths $(800-999)$ & 4 & 3.9 & 2 & 1.6 \\
\hline
\end{tabular}

a Code of the International Classification of Diseases (eighth revision) in parentheses.

Table 2. Observed $(O)$ and expected $(E)$ numbers of deaths among 234 welders exposed to high levels of chromium and followed until December 1984. The expected numbers are based on the national rates. (SMR = standardized mortality ratio, $95 \% \mathrm{Cl}=95 \%$ confidence interval)

\begin{tabular}{|c|c|c|c|c|}
\hline Cause of death ${ }^{\mathrm{a}}$ & 0 & $\mathrm{E}$ & SMR & $95 \% \mathrm{Cl}$ \\
\hline All $(1-999)$ & 32 & 44.2 & 0.72 & $0.49-1.02$ \\
\hline All tumors $(140-209)$ & 10 & 10.5 & 0.95 & $0.45-$ \\
\hline Tumor in rectum (154) & 2 & 0.5 & 4.31 & $0.52-15.6$ \\
\hline $\begin{array}{l}\text { Tumor in trachea, } \\
\text { bronchus and lung (162) }\end{array}$ & 5 & 2.0 & 2.49 & $0.80-5.81$ \\
\hline $\begin{array}{l}\text { Ischemic heart disease } \\
(410-414)\end{array}$ & 10 & 15.3 & 0.65 & $0.31-1.20$ \\
\hline Violent deaths $(800-999)$ & 6 & 5.5 & 1.08 & $0.39-2.35$ \\
\hline
\end{tabular}

a Code of the International Classification of Diseases (eighth revision) in parentheses.
When the welders with a high-exposure level were compared with those with a low-exposure level, the total number of deaths was about the same after stratification for age (table 4). The number of deaths due to ischemic heart disease and violence was about the same, but the number of pulmonary tumors was significantly higher in the high-exposure cohort after stratification for age.

\section{Discussion}

The outcome of the cohort of 234 welders exposed to high levels of chromium has been published once before, in 1980 (22), after the cohort was followed until December 1977. However the presented expectancy numbers in that study were based on a computer program which, several years after the publication, was found to make erroneous calculations of expected numbers from person-years and incidence rates. The correct calculations are presented in table 1 . The computer program underestimated the expected values and calculated the deaths from pulmonary tumors to be 0.7 instead of 0.9 .

The ideal reference population for welders exposed to high levels of chromium is welders who are exposed to the same general environment except for the exposure of particular interest. The welders exposed to low levels of chromium are theoretically a good

Table 3. Observed $(\mathrm{O})$ and expected $(E)$ numbers of deaths among 208 welders exposed to low levels of chromium and followed until December 1984. The expected numbers are based on the national rates. (SMR = standardized mortality ratio, $95 \% \mathrm{Cl}=95 \%$ confidence interval)

\begin{tabular}{lrrrc}
\hline Cause of death $^{\mathrm{a}}$ & O & E & SMR & $95 \% \mathrm{Cl}$ \\
\hline All (1-999) & 47 & 66.8 & 0.70 & $0.51-0.93$ \\
All tumors (140-209) & 10 & 16.1 & 0.62 & $0.29-1.14$ \\
Tumor in stomach (151) & 3 & 1.8 & 1.67 & $0.34-4.89$ \\
$\begin{array}{l}\text { Tumor in trachea, } \\
\text { bronchus and lung (162) }\end{array}$ & 1 & 3.0 & 0.33 & $0.00-1.84$ \\
$\begin{array}{l}\text { Ischemic heart disease } \\
\text { (410-414) }\end{array}$ & 18 & 24.5 & 0.74 & $0.43-1.16$ \\
Violent deaths (800-999) & 3 & 6.0 & 0.50 & $0.10-1.47$ \\
\hline
\end{tabular}

a Code of the International Classification of Diseases (eighth revision) in parentheses.

Tabie 4. Crude risk ratio (CRR), based on crude rates, and risk ratio (RR) calculated after stratification in three age categories, for the comparison between 234 welders exposed to high levels of chromium (contributing 5324 person-years) and 208 welders exposed to low levels of chromium (contributing 5273 person-years). $(95 \% \mathrm{Cl}=95 \%$ confidence interval)

\begin{tabular}{|c|c|c|c|c|}
\hline Cause of death ${ }^{a}$ & CRR & $95 \% \mathrm{Cl}$ & $\mathrm{RR}$ & $95 \% \mathrm{Cl}$ \\
\hline All $(1-999)$ & 0.67 & $0.43-1.05$ & 0.98 & $0.64-1.50$ \\
\hline All tumors $(140-209)$ & 0.99 & $0.40-2.48$ & 1.61 & $0.67-3.85$ \\
\hline Tumor in trachea, bronchus and lung (162) & 4.95 & $0.72-34.2$ & 7.01 & $1.32-37.3$ \\
\hline Ischemic heart disease $(410-414)$ & 0.55 & $0.26-1.18$ & 0.86 & $0.39-1.87$ \\
\hline Violent deaths $(800-999)$ & 1.98 & $0.51-7.70$ & 1.53 & $0.42-5.59$ \\
\hline
\end{tabular}

a Code of the International Classification of Diseases (eighth revision) in parentheses. 
reference population; however, a major drawback is the small size of the group. The general male population of Sweden is not an ideal reference population as it contains persons with, eg, chronic diseases, drug addicts and unemployed, who in general have a higher mortality than a working population. When the general population is used as reference, the lower than expected number of total deaths is referred to this incomparability between welders and referents generally known as the "healthy worker effect" (17).

The increase in pulmonary tumors in this study might be related to the exposure to hexavalent chromium in the welding fumes. Workers exposed to easily soluble hexavalent chromium in the chromium plating industry showed a higher incidence of tumors $(4,20)$ or a higher incidence of pulmonary tumors than would have been expected $(4,31)$. The Nordic Expert Group on the Documentation of Occupational Exposure Limits suggests that both chromates and chromic acid should be regarded as carcinogens (19). One previous study of chromium- and nickel-exposed welders revealed an increased risk of cancer; however some cases of mesothelioma suggested a confounding exposure from asbestos (3).

Nasal and sinonasal tumors have been associated with exposure to stainless steel welding fumes (9), but no such tumors were observed in the present study.

According to the information given by representatives from the different companies and the Swedish State Railways, it seems reasonable to assume that asbestos exposure was very low in the selected cohorts. - Pleural plaques discovered in a radiographic examination are an indicator of previous asbestos exposure. In a cross-sectional study of stainless steel welders none of 37 men above the age of 40 years had pleural plaques (29) and among 113 railway track welders one man had such plaques (24). The welder with pleural plaques had been exposed to asbestos prior to his employment as a welder. In Uppsala County $1.3 \%$ of the male population in the same age category had pleural plaques (10). These data indicate that these two cohorts of welders had not been excessively exposed to asbestos.

Male welders in Sweden have, on the whole, smoked more frequently than the general male population (25). In a register-linking study of 23000 welders, the rate ratio for pulmonary tumors decreased about $8 \%$ after correction for smoking habits, from 1.42 to 1.30 (23). In other words, the expected number of deaths based on the national rates might be too low, as smoking habits are not taken into account. However, smoking as a confounder is unlikely to have a major influence on the comparison between the two cohorts of welders.

Considering the results of the mutagenic tests on welding fumes and the epidemiologic studies on workers exposed to chromic acid, it seems reasonable to assume that the excess number of pulmonary tumors in the high-exposure cohort of welders might have a causal connection with the inhalation of hexavalent chromium generated in stainless steel welding. Studies on larger samples will be needed in the future to verify or refute this assumption.

\section{Acknowledgments}

This study has been supported by a grant from the National Board of Occupational Safety and Health.

\section{References}

1. Andersson K, Anjou C-G, Brodin G, Kling H, Samuelsson P-J. EPIL.IN: Datain, ratin, cohort, search, stat: Datorprogram för kohort studier. Användarhandledning [EPILIN: datain, ratin, cohort, search, stat: Computer program for cohort studies. User manual]. University of Linköping, Linköping 1982.

2. Attfield MD, Ross RS. Radiological abnormalities in electric-arc welders. Br J Ind Med 35 (1978) 117-122.

3. Becker N, Claude J, Frentzel-Beyme R. Cancer risk of arc welders exposed to fumes containing chromium and nickel. Scand J Work Environ Health 11 (1985) 75-82.

4. Franchini I, Magnani F, Mutti A. Mortality experience among chromeplating workers: Initial findings. Scand J Work Environ Health 9 (1983) 247-252.

5. Fregert S, Ovrum P. Chromate in welding fumes with special reference to contact dermatitis. Acta Derm Venereol 43 (1963) 119-124.

6. Hallne U, Erlandsson A. Arbetsmiljöproblem vid svetsning: 3. Förekomst av svetsning i aluminium och rostfritt stål samt lödning med silverlod inom svensk tillverkningsindustri [Occurrence of welding of aluminum and stainless steel and soldering with silver-solder in Sweden]. Arbetarskyddsstyrelsen, Stockholm 1977. (Undersökningsrapport 1977:6).

7. Hansen K, Stern RM. Welding fumes and chromium compounds in cell transformation assays. J Appl Toxicol 5 (1985) 306-314.

8. Hedenstedt A, Jenssen D, Lidesten B-M, Ramel C, Rannug U, Stern RM. Mutagenicity of fume particles from stainless steel welding. Scand J Work Environ Health 3 (1977) 203-211.

9. Hernberg S, Westerholm P, Schultz-Larsen K, Degerth R, Kuosma E, Englund A, Engzell U, Hansen HS, Mutanen P. Nasal and sinonasal cancer: Connection with occupational exposures in Denmark, Finland and Sweden. Scand J Work Environ Health 9 (1983) $315-326$.

10. Hillerdal G. Pleural plaques: Occurrence, exposure to asbestos, and clinical importance. University of Uppsala, Uppsala 1980. (Doctoral dissertation).

11. Husgafvel-Pursiainen K, Kalliomäki P-L, Sorsa M. A chromosome study among stainless steel workers. J Occup Med 24 (1982) 762-766.

12. Koshi K. Effects of fume particles from stainless steel welding on sister chromatid exchanges and chromosome aberrations in cultured Chinese hamster cells. Ind Health 17 (1979) 39-49.

13. Koshi K, Yagami T, Nakanishi Y. Cytogenetic analysis of peripheral blood lymphocytes from stainless steel welders. Ind Health 22 (1984) $305-318$.

14. Lautner GM, Carver JC, Konzen RB. Measurement of chromium VI and chromium III in stainless steel welding fumes with electron spectroscopy for chemical analysis and neutron activation analysis. Am Ind Hyg Assoc J 39 (1978) $651-660$.

15. Littorin M, Högstedt B, Strömbäck B, Karlsson A, Welinder H, Mitelman F, Skerfving S. No cytogenetic ef- 
fects in lymphocytes of stainless steel welders. Scand J Work Environ Health 9 (1983) 259-264.

16. Maxild J, Andersen M, Kiel P, Stern RM. Mutagenicity of fume particles from metal arc welding on stainless steel in the Salmonella/microsome test. Mutat Res 56 (1978) 235-243.

17. McMichael AJ. Standardized mortality ratios and the "healthy worker effect": Scratching beneath the surface. J Occup Med 18 (1976) 165-168.

18. Miettinen OS. Theoretical epidemiology: Principles of occurrence research in medicine. John Wiley and Sons, New York, NY 1985.

19. Nordiska Expertgruppen för Gränsvärdesdokumentation. 8. Krom [Chromium]. Arbetarskyddsverket, Stockholm 1979. (Arbete och hälsa 1979:33) (English summary).

20. Royle H. Toxicity of chromic acid in the chromium plating industry. Environ Res 10 (1975) 39-53.

21. Selikoff IJ, Nicholson WJ, Lilis R. Radiological evidence of asbestos disease among ship repair workers. Am J Ind Med 1 (1980) 9-22.

22. Sjögren B. A retrospective cohort study of mortality among stainless steel welders. Scand J Work Environ Health 6 (1980) 197-200.

23. Sjögren B, Carstensen J. Cancer among Swedish welders and gas-cutters. In: Stern RM, Berlin A, Fletcher AC, Järvisalo J, ed. Health hazards and biological effects of welding fumes and gases. Excerpta Medica, Amsterdam 1986, pp 461-463.

24. Sjögren B, Persson J, Randma E, Swensson A. Arbetsmiljöproblem vid svetsning: 9. En tvärsnittsstudie av spårsvetsare vid SJ [A cross-sectional study of track welders at the Swedish State Railways]. Arbetarskyddsverket, Stockholm 1979, pp 7-38. (Arbete och hälsa
1979:28) (English summary).

25. Statistiska Centralbyrån. Rökvanor i Sverige: En postenkätundersökning våren 1963 [Smoking habits in Sweden]. Stockholm 1965. (English summary).

26. Stern RM. Assessment of risk of lung cancer for welders. Arch Environ Health 38 (1983) 148-155.

27. Thomsen E, Stern RM. A simple analytical technique for the determination of hexavalent chromium in welding fumes and other complex matricies. The Danish Welding Institute, Glostrup 1979.

28. Tola S, Kilpiö J, Virtamo M, Haapa K. Urinary chromium as an indicator of the exposure of welders to chromium. Scand J Work Environ Health 3 (1977) 192202.

29. Ulfvarson U, Hallne U, Bellander T, Sjögren B, Swensson $\AA$. Arbetsmiljöproblem vid svetsning: 5. Svetsning i rostfritt stål med metallbågsvetsning och gasbågsvetsning [Welding problems connected with work environment: 5 . Welding in stainless steel with metal arc-welding with covered electrodes and gas-shielded weldingl. Arbetarskyddsverket, Stockholm 1978. 86 p. (Arbete och hälsa 1978:8) (English summary).

30. Ulfvarson U, Hallne U, Bergström B, Hallberg B-O, Lantz S. Arbetsmiljöproblem vid svetsning: 6. Bågsvetsning av järnvägsräler vid Statens Järnvägar, kartläggning av luftföroreningar [Metal arc welding in railway tracks]. Arbetarskyddsverket, Stockholm 1978. 38 p. (Arbete och hälsa 1978:14) (English summary).

31. Waterhouse JAH. Cancer among chromium platers. Br J Cancer 32 (1975) 262.

Received for publication: 26 January 1987 